\title{
Study on Diversity of Zooplanktons from Kurnur Dam in Akkalkot, Maharashtra
}

\author{
Anirudhh D. Babare ${ }^{1 *}$, Mohan G. Babare ${ }^{2}$, Manik B. Tat ${ }^{3}$ \\ ${ }^{1}$ Research Scholar, Department of Zoology, A.C.S. College, Maharashtra, India \\ ${ }^{2}$ Director, Department of Zoology, A.C.S. College, Maharashtra, India \\ ${ }^{3}$ Associate Professor, Department of Zoology, A.C.S. College, Maharashtra, India
}

*Address for Correspondence: Mr. Anirudhh D. Babare, Research Scholar, Department of Zoology, A.C.S. College, Maharashtra, India

E-mail: ababare@rediffmail.com

Received: 13 Dec 2018/ Revised: 28 Mar 2019/ Accepted: 24 Jun 2019

\begin{abstract}
Background: The Kurnur Dam was one of the biggest water bodies present in Akkalkot tehsil in Maharashtra. Zooplanktons are bio-indicators of pollution and provide direct link between primary producers and high trophic level zooplanktons are the major mode of energy transfer between phytoplankton and fish. Zooplankton plays a vital role in the food chain of fish as animal food, which supplies amino acids fatty acids, vitamins.

Methods: For the present investigation water samples were collected from various sampling stations of the dam. The water was collected from selected sampling station of Dam and brought to the laboratory for further water analysis.

Results: During the investigation, the monthly periodic observations i.e. June 2015 to May 2016, the maximum numbers of annual percentages of Zooplankton were observed 10.22\% (Protozoa), 43.54\% (Rotifer), 22.20\% (Cladocera), and 24.03\% (Copepoda) at sampling stations.

Conclusion: In the present investigation, there are 16 species belonging to 04 different classes from Zooplankton diversity. The work has been concluded with future strategies for development of fish production as well as zooplankton diversity conservation of Kurnur Dam from Akkalkot. The Kurnur Dam was one of the biggest water bodies present in Akkalkot tehsil in Maharashtra.
\end{abstract}

Key-words: Aquatic ecosystem, Diversity, Kurnur Dam, Plankton, Zooplanktons

\section{INTRODUCTION}

The zooplankton community consists of on extremely diverse assemblage of invertebrate phyla zooplanktons indices variability among living organisms each species has its own value in ecosystem. These are sensitive to climatic conditions and plays vital role in indicating the presence or absence of fish species. Zooplanktons are bio-indicators of pollution and provide direct link between primary producers and high trophic level zooplanktons are the major mode of energy transfer between phytoplankton and fish. Zooplankton plays a

\section{How to cite this article}

Babare AD, Babare MG, Tat MB. Study on Diversity of Zooplanktons from Kurnur Dam in Akkalkot, Maharashtra. SSR Inst. Int. J. Life Sci., 2019; 5(4): 2335-2340.

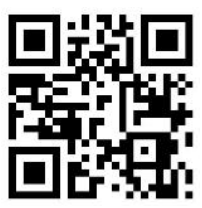

vital role in the food chain of fish as animal food, which supply amino acids fatty acids, vitamins ${ }^{[1]}$. Zooplankton is important aquatic organism occurring abundantly in all types of aquatic habits and plays a vital role in energy transfer in an aquatic ecosystem. It occupies an intermediate position in food web many of them feed upon bacteria and algae and in turn fed by numerous invertebrates, fishes and birds ${ }^{[2]}$. The presence and dominance of zooplankton species play very significant role in the functioning of freshwater ecosystem. Zooplankton diversity and their ecology greatly contribute to as understanding of the basic nature and general economy of aquatic habitats physic-chemical factors are also regulating zooplankton population in water body. Zooplanktons species are consumed by a variety of secondary consumers including commercial important groups of many of crustaceans as well as fish species. Fishes are rich source of food and nutrition and become an important and delicious food for man. Fishes 
also provide byproducts including fish oil, which is having a good medicinal food value. The quantity of zooplanktons in water provides significant information about the available sources for supporting life for fishery development. In present days, the Biodiversity is in danger because due to pollution and human activities conservation of biodiversity is essential so it is compulsory to keep update knowledge of the every aquatic species diversity. The density of planktons in water body determines stocking rate of fishes because they are the chief sources of the food of commercially important fishes.

There was no back record found about the zooplankton diversity of Kurnur Dam near Akkalkot in solapur district, hence this task was undertaken. Zooplanktons are heterotrophic, minute aquatic organisms which play important role in food web. They are important link between primary producers and high tropic levels. Freshwater zooplanktons mainly contain protozoa, rotifers, cladocerans copepods, and ostracodes.

\section{MATERIALS AND METHODS}

For the present investigation water samples were collected from the four sampling stations of Dam, in Akkalkot, Maharashtra, India. The water was collected directly from each selected sampling station of Dam. The samples were transferred to the bottle and brought to the laboratory without disturbances. The water samples were collected by monthly intervals from the sampling stations for a period of one year. The samples were collected during morning hours. During the present study period the water samples collected from the Kurnur dam with the interval of the month for the period of the year (June 2015 to May 2016) from the selected spots of Kurnur dam. For the collection of planktons, 200 liters of water samples were filtered through plankton net numbers 25 bolting silk cloth Pundhir and Rana ${ }^{\text {[3]. The }}$ collected planktonic sample was concentrated to a $50 \mathrm{ml}$ volume and it was preserved into $4 \%$ formalin solution for further study. Each planktonic replicate identified under the microscope with its standard identification and its monographs as well as keys which were suggested by APHA ${ }^{[4]}$; Tonapi ${ }^{[5]}$ etc.

\section{RESULTS}

Protozoa- During the year of investigation, the monthly period observation was June 2015 to May 2016. The maximum number of group Protozoa was observed at sampling stations $A, B, C$, and $D$ respectively. In the observation of this group, there were 3 species were recorded during the investigation period i.e. Balantidium sp., Ceratium sp., and Stentor sp., etc. Out of these all 3 species the Stentor sp. was dominant than other species.

Rotifer- In June 2015 to May 2016, the maximum number of group Rotifer were observed at sampling stations $A, B, C$, and $D$ respectively. In the observation of this group, there are 7 species were recorded during investigation period i.e. Brachionus angularis sp., $B$. caudatus sp., B. calyciflorus sp., Filinia opoliensis sp., Keatella procurca sp., $K$. cochlearis sp. and Lecanebulla sp. etc. Out of these all 7 species, the $K$. procurca was dominant than other species.

Cladocera- During the year of investigation, the Maximum number of Group Cladocera were observed at sampling stations $A, B, C$, and $D$ respectively. In the observation of this group, there are 6 species were recorded during the investigation period i.e. Daphnia carinata sp., Chydorus ciliates sp., and Monia brachiate sp., etc. Out of these all 6 species, the D. carinata was dominant than other species.

Copepoda- During the investigation, the monthly period observation was undertaken, i.e. June 2015 to May 2016; the Maximum number of Group Copepoda was observed at sampling stations $A, B, C$, and $D$ respectively. In the observation of this group, there were 3 species were recorded during the investigation period i.e. Mesocyclops leucarati sp., M. hyalinus sp., and Nauplius larvae sp., etc. Out of these all 3 species, the $N$. larvae was dominant than other species. 
Table 1: Monthly variation in Zooplankton of Kurnur Dam from June 2015 to May 2016

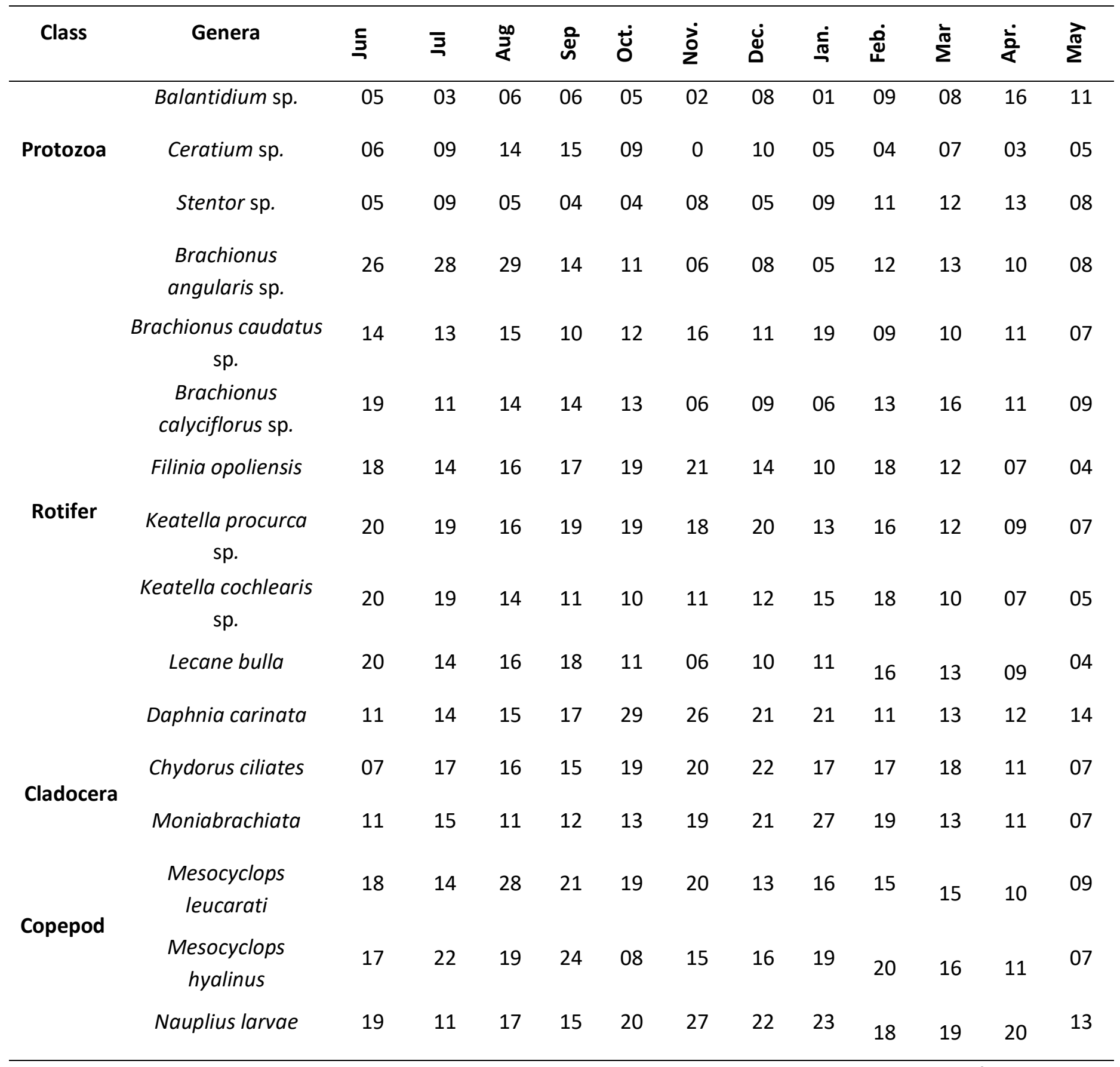

Annual percentage of Zooplankton- Table 2 shows the monthly as well as seasonal variations of annual percentage of Zooplankton at four different sampling stations of the Kurnur Dam from June 2015 to May 2016. During the year of investigation, the maximum number of annual percentage of Zooplankton was observed $10.22 \%, 43.54 \%, 22.20 \%$, and $24.03 \%$ at sampling stations $A, B, C$ and $D$ respectively, i.e. in this the maximum percentage was Rotifer group i.e. $43.54 \%$ and the minimum value of annual percentage of Zooplankton was observed protozoa group i.e. $10.22 \%$ from sampling stations $A, B, C$, and $D$ respectively.

Table 2: Annual percentage of Zooplankton of Kurnur Dam from June 2015 to May 2016

\begin{tabular}{cc}
\hline Classes & Annual percentage of Zooplankton \\
\hline Protozoa & $10.22 \%$ \\
Rotifer & $43.54 \%$ \\
Cladocera & $22.20 \%$ \\
Copepod & $24.03 \%$ \\
\hline
\end{tabular}




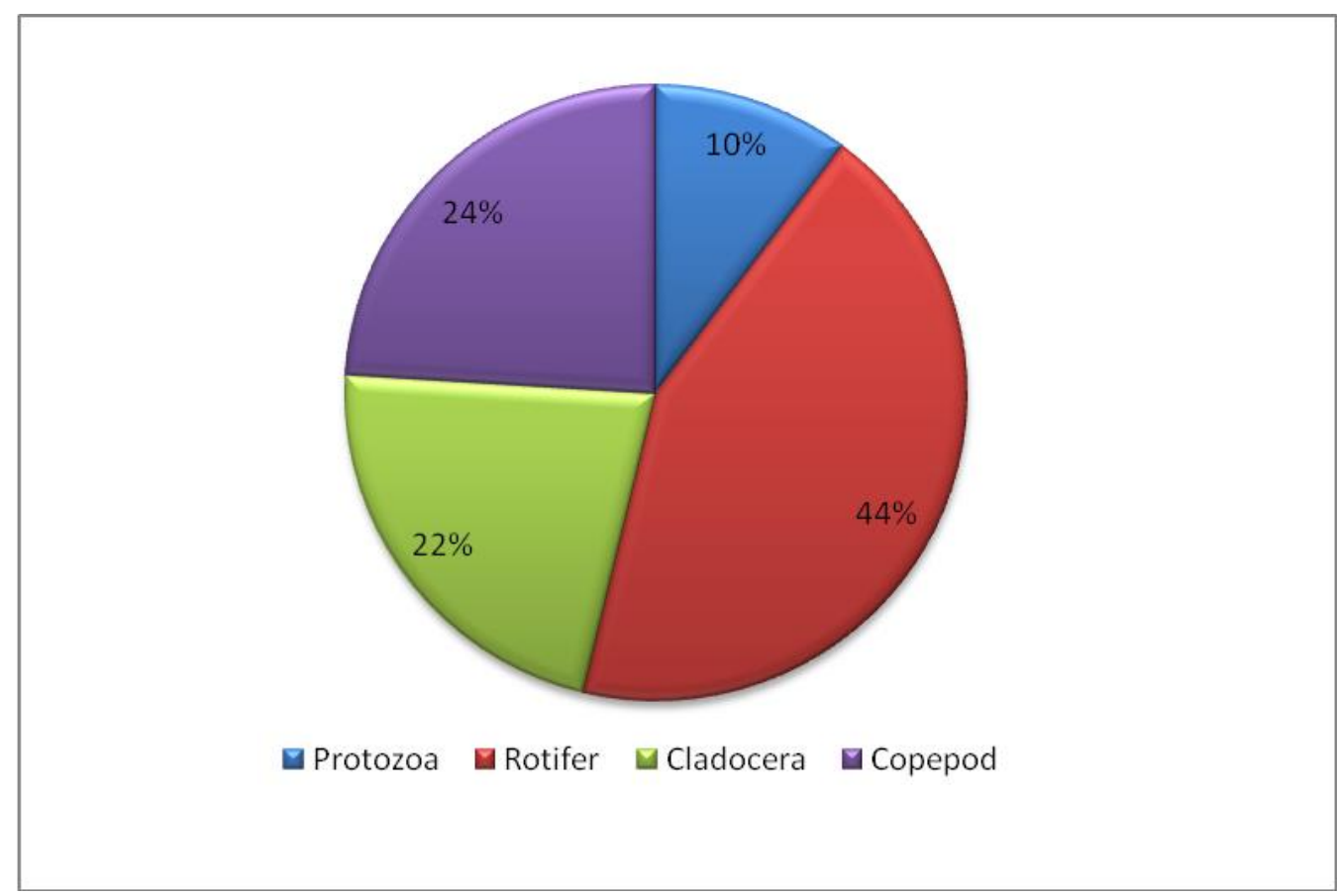

Fig. 1: Annual Percentage of Zooplankton of Kurnur Dam from June 2015 to May 2016

\section{DISCUSSION}

The zooplanktons are the microscopic structure freeswimming living components present in the water body. They feed on the phytoplankton in water body so it also called as primary consumer. The zooplanktonic study from Kurnur Dam had been distributed into 4 groups i.e. Protozoans, Rotifers, Cladoceraand Copepod.

The distribution of various species depended on the physic-chemical parameter ${ }^{[5]}$ such as temperature, conductivity, $\mathrm{pH}$, chloride, and free $\mathrm{CO}_{2}$ content of water. In the present study, among all groups of zooplanktons, the Rotifers was found dominant in all groups due to its distribution and similarity of results was previously observed by many researchers Abdullahi et al. ${ }^{[6]}$; Adeyemi et al. ${ }^{[7]}$; APHA ${ }^{[8]}$; Balamurugan et al. ${ }^{[9]}$; and Benarjee et al. ${ }^{[10]}$.

During the observation of Protozoans group, there 3 species were recorded during investigation i.e. Balantidium sp., Ceratium sp., Stentor sp. etc. Out of these all 3 species, the Stentor was dominant than other species and such type of results were previously observed by Bhagat and Meshram [11]; Boxshall and Strong ${ }^{[12]}$.

The observation of Rotifer group there were 7 species were recorded during investigation period i.e. Brachionus angularis sp., B. caudatus sp., B. calyciflorus sp., Filinia opoliensis sp., Keatella procurca sp., $K$. cochlearis sp., and Lecanebulla sp. etc. Out of these all 7 species the $K$. procurca was dominant than other species and such type of results were previously observed by Boxshall and Evstigneeva ${ }^{[13]}$ and Davies et al. ${ }^{[14]}$.

During the observation of Cladocera group, there were 6 species recorded during investigation period i.e. Daphnia carinata, Chydorus ciliates, and Monia brachiate, etc. Out of these all 6 species the Daphnia carinata was dominant than other species and such type of results was previously observed by Dhanapathi ${ }^{[15]}$; Devika et al. [16]; Gayathri et al. ${ }^{[17]}$; Goswami and Mankodi ${ }^{[18]}$. During the observation of Copepoda group there 3 species were recorded during investigation i.e. Mesocyclops leucarati, M. hyalinus, and Nauplius larvae etc. Out of these all 3 species, the $N$. larvae was dominant than other species and such type of results were previously observed by Jalilzadeh et al. ${ }^{[19]}$; Raghunathan and Kumar ${ }^{[20]}$.

\section{CONCLUSIONS}

The diversity of zooplanktons is richer in number and presence and dominance of zooplankton species play very significant role in the functioning of freshwater ecosystem. In the present investigation, there were 16 species belonging to four different classes from Zooplankton diversity. The quantity of zooplanktons in water provided significant information about the available sources for supporting life for fishery development. In present days, the biodiversity is in danger because due to pollution and human activities. Conservation of biodiversity is essential so it is 
compulsory to keep update knowledge of every aquatic species diversity. The density of planktons in water body determined stocking rate of fishes because they were the chief sources of the food of commercially important fishes as well as development in production of inland fishery sector. The presence and dominance of zooplankton species played a very significant role in the functioning of freshwater ecosystem.

We can do future study for the development of fish production as well as zooplankton diversity conservation of Kurnur Dam from Akkalkot, Maharashtra. This study can be helpful to future fishery development from the present status of Dam.

\section{ACKNOWLEDGMENTS}

Authors were thankful to the Management Balaghat Education Society, Naldurg. Dist. Osmanabad for providing necessary library and laboratory facilities.

\section{CONTRIBUTION OF AUTHORS}

Research concept- Dr. Mohan G. Babare

Research design- Manik B. Tat

Supervision- Manik B. Tat

Materials- Mr. A. D. Babare

Data collection- Mr. A. D. Babare

Data analysis and Interpretation- Mr. A. D. Babare

Literature search- Mr. A. D. Babare

Writing article- Mr. A. D. Babare

Critical review- Mr. A. D. Babare

Article editing- Manik B. Tat

Final approval- Dr. Mohan G. Babare

\section{REFERENCES}

[1] Akin-Oriola FA. Zooplankton associations and environmental factors in Ogunpa and Ona Rivers. Nigeria. Rev. Biol. Trop., 2003; 51(2): 391-98.

[2] Basu BK, Pick FR. Factors regulating phytoplankton and zooplankton development in a temperate river. Limnol. Oceanogr., 1996; 41: 1572-77.

[3] Pundhir P, Rana KS. Pollution dynamics of phytoplankton in the wetland area of Keoladeo National Park, Bharatpur (Rajasthan). Eco. Env. Cons., 2002; 8(3): 235-53.

[4] APHA: Standard methods for the examination of water, sewage and industrial wastes. $14^{\text {th }} \mathrm{Edn}$. APHA Inc., New York: 1985; pp. 1193.
[5] Tonapi GJ. Freshwater animals of India. An ecological approach, Oxford and IBH, 1980.

[6] Abdullahi HA, Azionu BC, Ajayi O. Checklist of zooplankton in culture tanks at NIFFRI Green House, New Bussa. Proceedings of the $22^{\text {nd }}$ Annual Conference of Fisheries Society of Nigeria (FISON), Kebbi., 2007; 1: 284-90.

[7] Adeyemi SO, Adikwu LA, Akombu PM, Iyela JT. Survey of zooplankton and macro invertebrates of Gbedikere Lake Bassa, Kogi State, Nigeria. Int. J. Salt Lake Res., 2009; 2(1): 37-44.

[8] APHA. Standard methods for the examination water and waste water American public health Association $19^{\text {th }}$ Edition Washington, U.S.A., 1989.

[9] Balamurugan S, Mohideen BMG, Subramanyam P. Biodiversity of zooplankton in Cauveri River at Tirucherapalli, Tamilnadu. J. Aqua. Bio., 1999;14(142): 21-25.

[10]Benarjee GK, Srikanth G, Ramu K, Narasimha R, Ravinder B. The Climatic Influence on Zooplanktonic Population in Historical Lake of Kakatiya Dynasty. Proc. of $8^{\text {th }}$ Indian Fisheries Forum, 2008; pp. 22-26.

[11]Bhagat VB, Meshram CB. Zooplankton dynamics of Ambadi dam, near Akot, dist. Akola, Maharashtra. J. Aqu. Biol., 2007; 22(1): 19-20.

[12]Boxshall GA, Strong EE. An extraordinary shift in life habit in a genus of cyclopid copepods from Lake Tanganyika. Zool. J. Linnean. Soc., 2006; 146: 275-85.

[13]Boxshall GA, Evstigneeva TD. The evolution of species flocks of copepods in Lake Baikal: apreliminary analysis. In: Martens, K., B. Goddeeris \& G. Coulter (Eds), and Speciation in Ancient Lakes. Arch. Hydrobiol. Ergebn. Limnol., 1994; 44: 235-45.

[14]Davies OA, Abowei JFN, Otene BB. Seasonal abundance and distribution of plankton of Minichinda stream, Niger Delta, Nigeria. Am. J. Sci. Res., 2009; 2: 20-30.

[15]Dhanapathi MVSSS. Taxonomic notes on the Rotifers from India (from 889-2000), IAAB, Hyderabad (A.P.) India, 2000.

[16]Devika R, Rajendran A, Selvapathy P. Variation studies on the physico-chemical and biological characteristics at different depths in model waste stabilsation tank. Pollut. Res., 2006; 24: 771-74. 
[17]Gayathri S, Latha N, Mohan MR. Studies on population dynamics and seasonal abundance of zooplankton community in Doddavoderahalli lake, Bangalore. Int. J. Emerg. Trends Eng. Dev., 2014; 4(1): 50-55.

[18]Goswami AP, Mankodi PC. Study on Zooplankton of Fresh Water Reservoir Nyari-II Rajkot district, Gujarat, India. J. Biol. Sci, 2012; 1(1): 30-34.
[19]Jalilzadeh AKK, Yamakanamardi SM, Altaff K. Abundance of zooplankton in three contrasting lake of Mysore city, Karnataka state, India, Sengupta M. and Dalwan R (eds.) Proceedings of Taal: The $12^{\text {th }}$ World lake Conference, 2007; 464-69.

[20]Raghunathan MB, Kumar RS. Cladocera (Crustacea) of Tamil Nadu-Checklist and Bibliography. Zoos. Print J., 2002; 17(12): 959-61.

\section{Open Access Policy:}

Authors/Contributors are responsible for originality, contents, correct references, and ethical issues. SSR-IIJLS publishes all articles under Creative Commons Attribution- Non-Commercial 4.0 International License (CC BY-NC). https://creativecommons.org/licenses/by-nc/4.0/legalcode (c) (1) (9) 